\title{
HUBUNGAN STATUS GIZI DENGAN ERUPSI GIGI PERMANEN SISWA SD NEGERI 70 MANADO
}

\author{
${ }^{1}$ Virginia A. R. Lantu \\ ${ }^{2}$ Shirley E. S. Kawengian \\ ${ }^{3}$ Vonny N. S. Wowor \\ ${ }^{1}$ Kandidat Skripsi Program Studi Kedokteran Gigi Fakultas Kedokteran \\ ${ }^{2}$ Bagian Gizi Fakultas Kedokteran \\ ${ }^{3}$ Program Studi Kedokteran Gigi Fakultas Kedokteran Fakultas Kedokteran \\ Universitas Sam Ratulangi Manado \\ Email: virginiaprilita@yahoo.com
}

\begin{abstract}
Tooth eruption is defined as movements of the teeth to oral cavity or as a process appearance of the teeth which begins during teeth inside the jaws. It was a different variation to each childre's. Nutritional status is one of important that play role during tooth eruption process. Related to another research that has found children with normal category of nutritional status have a normal process of tooth eruption. Instead, there was interference to children's with a malnutrition status. This study aimed to analyze the relation between nutritional status and tooth eruption of children in SDN 70 Manado. Total population of this study was taken from $1^{\text {st }}$ up to $6^{\text {th }}$ grades within the age group 6-12 years old. Samples were 83 respondents who met the inclusion and exclusion criteria. Anthropomentric and visual checking was used for measurement of nutritional status and permanent tooth eruption status. The results showed that most respondents had normal height and weight as well as normal process of permanent tooth eruption. Children who had malnutrition status were also had failure in permanent tooth eruption. The chi-square test showed a significant relation between nutritional status and permanent tooth eruption in SDN 70 Manado.
\end{abstract}

Keywords: nutritional status, permanent tooth eruption

\begin{abstract}
Abstrak: Erupsi gigi didefinisikan sebagai pergerakan atau proses munculnya gigi ke arah rongga mulut yang dimulai sejak gigi berada di dalam tulang alveolar dan merupakan proses yang bervariasi pada setiap anak. Status gizi merupakan salah satu faktor yang berperan penting pada pertumbuhan dan perkembangan gigi termasuk tahapan erupsi gigi. Berdasarkan beberapa penelitian terdahulu ditemukan bahwa anak-anak dengan status gizi baik, proses erupsi gigi permanen umumnya berjalan normal sedangkan anak-anak dengan status gizi kurang baik beresiko mengalami gangguan pada proses erupsi gigi. Penelitian ini bertujuan untuk mengetahui apakah terdapat hubungan antara status gizi dengan erupsi gigi permanen siswa SD Negeri 70 Manado. Populasi pada penelitian ini yakni siswa kelas I hingga kelas VI yang berusia 6 - 12 tahun, Sampel penelitian ialah seluruh anggota populasi dan memenuhi kriteria inklusi dan ekslusi dengan jumlah 83 sampel dengan menggunakan metode total sampling. Data diambil melalui pengukuran antropometri dan pemeriksaan visual pada rongga mulut. Hasil penelitian yang didapatkan menunjukkan sebagian besar responden memiliki tinggi dan berat badan normal sesuai usianya, diikuti oleh yang berstatus gizi kurus, obesitas dan gemuk. Status erupsi gigi permanen sebagian besar menunjukkan telah erupsi. Hasil uji statistik dengan menggunakan uji Chi-square menunjukkan bahwa terdapat hubungan yang signifikan antara status gizi dengan erupsi gigi permanen siswa SD Negeri 70 Manado.
\end{abstract}

Kata kunci: status gizi, erupsi gigi permanen 
Asupan zat gizi sangat penting dan mendasar dalam kehidupan manusia yang berfungsi sebagai penghasil energi, pembangun, pemelihara dan pengatur proses kehidupan. ${ }^{1,2}$ Sejak terjadi pembuahan manusia bergantung pada zatzat gizi untuk pertumbuhan, perkembangan dan kelangsungan hidupnya. ${ }^{3}$ Asupan zat gizi yang tepat memiliki dampak yang sangat besar.

Pada masa kanak-kanak asupan zat gizi yang baik dibutuhkan untuk pertumbuhan fisik yang normal dan perkembangan otak untuk memperoleh pengetahuan baik didalam maupun diluar sekolah. ${ }^{4}$ Dampak dari asupan zat gizi yang tidak tepat akan terefleksi pada pola pertumbuhan anak, baik secara umum maupun secara khusus pada erupsi gigi permanen dalam rongga mulut. $^{3}$

Asupan zat gizi yang adekuat sangat dibutuhkan selama masa awal tumbuh kembang. ${ }^{5}$ Pertumbuhan dan perkembangan gigi dan mulut dipengaruhi zat gizi baik secara sistemik maupun secara lokal. Pada tahap dini pertumbuhan gigi dipengaruhi oleh sejumlah zat gizi, yaitu Calcium, Phosfor, Fluor dan vitamin dalam diet. ${ }^{6}$ Kurangnya asupan zat gizi dapat berdampak antara lain pada keterlambatan erupsi gigi, sebaliknya kelebihan zat gizi juga memberikan dampak yang tidak diharapkan bagi pertumbuhan dan perkembangan gigi. Pada tahap pertumbuhan dan perkembangan gigi, tidak sedikit ditemukan kasus anak yang mengalami gangguan erupsi gigi akibat tidak terpenuhinya asupan zat gizi. Hal ini dapat menyebabkan kelainan-kelainan pada pertumbuhan gigi. $^{7}$

Indonesia mengalami masalah gizi ganda yaitu kekurangan gizi dan kelebihan gizi yang berakibat pada penurunan kualitas sumber daya manusia suatu bangsa dan salah satu penyebab kematian di Indonesia. ${ }^{1}$ Kekurangan gizi terjadi akibat asupan gizi di bawah kebutuhan dan kelebihan gizi terjadi akibat asupan gizi melebihi kebutuhan. ${ }^{8}$ Penilaian terhadap kondisi gizi seorang sebagai akibat dari konsumsi makanan dan penggunaan zat-zat gizi ditentukan berdasarkan pemeriksaan status gizi. Status gizi dikategorikan atas status gizi sangat kurus, status gizi kurus, status gizi baik dan status gizi gemuk (obesitas). ${ }^{9}$ Penilaian status gizi dibutuhkan untuk menetapkan status kesehatan perorangan atau kelompok yang dipengaruhi oleh konsumsi dan utilisasi zat-zat gizi. $^{3}$

Menurut data Riset Kesehatan Dasar (RISKESDAS) tahun 2010 di Indonesia, prevalensi status gizi anak usia 6-14 tahun berdasarkan Indeks Massa Tubuh (IMT/U) berbeda-beda. Prevalensi status gizi kurus $7,6 \%$, status gizi gemuk $9,2 \%$ dan prevalensi status gizi normal $78,6 \%$. Di Sulawesi Utara prevalensi status gizi kurus $5,4 \%$ dan status gizi gemuk $6,4 \%$ sedangkan status gizi normal yaitu $86,0 \%$. $^{10}$

SD Negeri 70 Manado merupakan salah satu sekolah dasar yang berada di seputaran wilayah kampus Universitas Sam Ratulangi, sehingga memudahkan penulis untuk melakukan penelitian di sekolah tersebut. Di samping itu Di wilayah ini banyak terdapat tempat berjualan berbagai jenis jajanan, sehingga memudahkan siswa untuk jajan. Berdasarkan observasi pendahuluan yang dilakukan peneliti didapati bahwa siswa SD tersebut sudah jarang membawa bekal makanan dari rumah dan banyak yang membeli jajanan saat istirahat. Seringkali jajanan memengaruhi nafsu makan anak, sehingga dapat memengaruhi asupan zat-zat gizi yang dibutuhkan oleh tubuh untuk tumbuh kembang. Kelebihan dan kekurangan zat gizi dapat pula berdampak pada gangguan erupsi gigi permanen anak. ${ }^{3}$ Alasan-alasan inilah yang melatarbelakangi penulis, sehingga melakukan penelitian tentang hubungan status gizi dan erupsi gigi permanen pada anak SD Negeri 70 Manado.

Tujuan penelitian ini ialah untuk mengetahui gambaran status gizi, untuk mengetahui gambaran erupsi gigi dan untuk mengetahui apakah ada hubungan antara status gizi dengan erupsi gigi permanen siswa SD Negeri 70 Manado. 
Manfaat penelitian ini terbagi atas:

1. Manfaat bagi pemerintah: Kiranya hasil penelitian ini dapat menjadi bahan kajian dalam upaya peningkatan kesehatan melalui program preventif dan promotif.

2. Manfaat bagi masyarakat: Melalui upaya peningkatan derajat kesehatan yang dilakukan oleh pemerintah, derajat kesehatan masyarakat akan semakin meningkat.

3. Manfaat bagi institusi pendidikan yaitu Program Studi Pendidikan Dokter Gigi Fakultas Kedokteran Universitas Sam Ratulangi Manado: Hasil penelitian ini dapat menjadi bahan pembanding dan referensi bagi penelitian selanjutnya.

4. Manfaat bagi peneliti: Peneliti memperoleh pengalaman untuk pertama kalinya melakukan penelitian dan menuangkannya dalam suatu bentuk tulisan ilmiah.

\section{METODE PENELITIAN}

Penelitian ini bersifat deskriptif analitik dengan rancangan potong lintang dimana pengukuran variabel bebas dan variabel terikat diambil pada waktu yang sama. Penelitian ini dilaksanakan di SD Negeri 70 Manado pada bulan Juni 2014.

Populasi dalam penelitian ini ialah seluruh siswa SD Negeri 70 Manado yang berusia $6-12$ tahun. Besar sampel pada penelitian ini ialah keseluruhan total populasi berdasarkan kriteria inklusi dan kriteria eksklusi dengan jumlah 83 responden.

Kriteria inklusi:

1. Bersedia menjadi subjek penelitian, dibuktikan dengan penandatanganan informed consent.

2. Hadir saat penelitian dilakukan

3. Bersikap kooperatif selama penelitian berlangsung

Kriteria eksklusi:

1. Berusia dibawah 6 tahun atau diatas 12 tahun

2. Terdaftar sebagai siswa namun sudah tidak aktif.

Analisis data menggunakan uji chi- square berskala ordinal dengan batas kemaknaan $\mathrm{a}=0.05$. Jika $\mathrm{p}$-value $>0,05$ maka tidak ada hubungan antara variabel bebas dengan variabel terikat sehingga $\mathrm{H}_{\mathrm{O}}$ tidak diterima. Sebaliknya jika p-value $\leq$ 0,05 maka terdapat hubungan antara variabel bebas dan variabel terikat sehingga hipotesis dapat diterima.

\section{HASIL PENELITIAN}

Karakteristik responden

Karakteristik yang diamati pada penelitian ini yaitu dibedakan menjadi dua yaitu meliputi umur dan jenis kelamin responden.

Berdasarkan Tabel 1diketahui bahwa kelompok umur 6 tahun berjumlah 9 responden (10\%), kelompok umur 7 tahun berjumlah 14 responden (16\%), kelompok umur 8 tahun berjumlah 10 responden (12\%), kelompok umur 9 tahun berjumlah 18 responden (21\%), kelompok umur 10 tahun berjumlah 14 responden (16\%), kelompok umur 11 tahun berjumlah 9 responden (10\%) dan kelompok umur 12 tahun berjumlah 9 responden (10\%). Jenis kelamin laki-laki berjumlah 45 responden (54,22\%) sedangkan untuk jenis kelamin perempuan berjumlah 38 responden $(45,78 \%)$.

Tabel 1. Distribusi karakteristik responden

\begin{tabular}{ccc}
\hline $\begin{array}{c}\text { Karakteristik } \\
\text { responden }\end{array}$ & $\mathrm{n}$ & $\%$ \\
\hline Umur & & \\
6 & 9 & $10,84 \%$ \\
7 & 14 & $16,86 \%$ \\
8 & 10 & $12,04 \%$ \\
9 & 18 & $21,68 \%$ \\
10 & 14 & $16,86 \%$ \\
11 & 9 & $10,84 \%$ \\
12 & 9 & $10,84 \%$ \\
\hline Jenis & & \\
kelamin & & \\
Laki-laki & 45 & $54,22 \%$ \\
Perempuan & 38 & $45,78 \%$ \\
\hline
\end{tabular}

\section{Gambaran status gizi dan erupsi gigi permanen}

Berdasarkan Tabel 2 diketahui bahwa responden dengan kategori status gizi kurus 
Lantu, Kawengian, Wowor: Hubungan status gizi...

berjumlah 15 responden (18\%), status gizi baik dengan jumlah 49 responden (59,03\%), status gizi gemuk dengan jumlah 8 responden $(9,63 \%)$ dan status gizi sangat gemuk atau lebih dikenal dengan obesitas dengan jumlah 11 responden (13,25\%). Gambaran erupsi gigi permanen yakni sudah erupsi dengan jumlah 46 responden (55,42\%) dan belum erupsi dengan jumlah 37 (44,57\%).

Tabel 2. Distribusi gambaran status gizi dan erupsi gigi permanen

\begin{tabular}{ccc}
\hline Status Gizi & $\mathrm{n}$ & $\%$ \\
\hline Sangat kurus & 0 & $0 \%$ \\
Kurus & 15 & $18,07 \%$ \\
Baik & 49 & $59,03 \%$ \\
Gemuk & 8 & $09,63 \%$ \\
Obesitas & 11 & $13,25 \%$ \\
\hline Erupsi gigi & & \\
permanen & & \\
\hline Belum Erupsi & 37 & $44,57 \%$ \\
Sudah Erupsi & 46 & $55,42 \%$ \\
\hline
\end{tabular}

Berdasarkan Tabel 3 diketahui bahwa status erupsi gigi permanen berdasarkan status gizi sangat kurus ialah belum erupsi dengan jumlah 0 responden dan sudah erupsi dengan jumlah 0 responden. Kategori status gizi kurus ialah belum erupsi berjumlah 11 responden dan yang sudah erupsi dengan jumlah 4 responden. Kategori status gizi normal ialah belum erupsi dengan jumlah 23 responden dan sudah erupsi berjumlah 26 responden. Kategori status gizi gemuk ialah belum erupsi dengan jumlah 1 responden dan yang sudah erupsi berjumlah 7 responden. Kategori status gizi obesitas ialah belum erupsi dengan jumlah 2 responden dan sudah erupsi dengan jumlah 9 responden.

Data hasil analisis hubungan antara status gizi dengan erupsi gigi permanen siswa SD Negeri 70 Manado dengan menggunakan uji Chi-square menunjukkan nilai p-value 0,006 (p: $\leq 0.05)$ hal ini menunjukkan bahwa terdapat hubungan yang signifikan antara status gizi dengan erupsi gigi permanen siswa SD Negeri 70 Manado sehingga hipotesis dapat diterima.
Tabel 3. Hubungan status gizi dengan erupsi gigi permanen

\begin{tabular}{ccccccc}
\hline $\begin{array}{c}\text { Status } \\
\text { Erupsi }\end{array}$ & \multicolumn{6}{c}{ Status Gizi } \\
\hline & sk & $\mathrm{k}$ & $\mathrm{n}$ & $\mathrm{g}$ & obes & Jumlah \\
\hline $\begin{array}{c}\text { Belum } \\
\text { erupsi }\end{array}$ & - & 11 & 23 & 1 & 2 & 37 \\
$\begin{array}{c}\text { Sudah } \\
\text { erupsi }\end{array}$ & - & 4 & 26 & 7 & 9 & 46 \\
\hline Total & 0 & 15 & 49 & 8 & 11 & 83 \\
\hline
\end{tabular}

\section{BAHASAN}

\section{Gambaran status gizi siswa SD Negeri 70 Manado}

Kelompok anak usia sekolah mempunyai laju pertumbuhan fisik yang lambat tetapi konsisten dan secara terus menerus memperoleh pendewasaan dalam keterampilan motorik serta menunjukan peningkatan yang berarti dalam keterampilan kognitif, sosial dan emosional. ${ }^{3}$ Keadaan gizi anak dipengaruhi oleh faktor langsung seperti konsumsi makanan dan faktor tidak langsung seperti faktor ekonomi yang berkaitan dengan masalah pekerjaan dan penghasilan suatu keluarga serta faktor pengetahuan yang berkaitan dengan masalah pemilihan dan penyediaan makanan bergizi dan beraneka ragam. ${ }^{11}$

Hasil penelitian menunjukan bahwa status gizi siswa SD Negeri 70 Manado sebagian besar $\mathbf{( 5 9 , 0 4 \% )}$ berada pada kategori status gizi baik. Hasil tersebut menunjukkan adanya keseimbangan dari penggunaan zat-zat gizi yang terkandung dalam makanan yang dikonsumsi. Hasil penelitian ini ditunjang oleh pendapat dari Suhardjo yang mengatakan bahwa setiap orang akan mempuyai status gizi baik jika makanan yang dikonsumsi mampu meyediakan zat-zat gizi dalam jumlah yang cukup bagi tubuh. ${ }^{17}$ Anak-anak yang termasuk pada kategori status gizi normal memungkinkan pertumbuhan fisik, perkembangan otak, kemampuan kerja dan kesehatan secara umum pada tingkat optimal, sehingga dapat meningkatkan kualitas hidup serta mencegah terjadinya morbiditas dan mortalitas. ${ }^{3,9,18}$

Berdasarkan hasil penelitian juga 
diketahui 18,07\% responden berada pada kategori status gizi kurus, Status gizi kurus terjadi akibat tubuh mengalami kekurangan satu atau lebih zat-zat gizi esensial. Hal ini sejalan dengan penelitian yang dilakukan oleh Kusumawati yang menyebutkan bahwa anak yang memiliki status gizi kurus disebabkan oleh masukan energi dan protein yang sangat kurang dan dalam jangka waktu yang lama. ${ }^{27}$ Widyakarya Nasional Pangan dan Gizi menyebutkan bahwa anak usia sekolah yang kekurangan gizi akan mengakibatkan terganggunya proses pertumbuhan dan perkembangan, anak menjadi cepat lelah, sakit-sakitan serta mengalami kesulitan dalam memahami pelajaran. $^{28}$

Hasil penelitian juga menunjukkan bahwa sebanyak 09,63\% responden berada pada kategori status gizi gemuk dan $13,25 \%$ berada pada kategori sangat gemuk. Kategori status gizi gemuk dan sangat gemuk diakibatkan karena tubuh memperoleh zat-zat gizi dalam jumlah yang lebih atau sangat banyak. Misnadiarly menyebutkan bahwa kategori status gizi gemuk dan sangat gemuk jarang dijumpai pada keluarga yang hidup dalam kemiskinan dan biasanya sangat berkaitan dengan kurangnya pengetahuan tentang pemenuhan gizi seimbang pada anak. ${ }^{30}$ Suhardjo berpendapat bahwa status gizi gemuk biasanya dialami oleh anak-anak yang mempunyai seorang ibu yang bekerja.

Para ibu yang bekerja biasanya tidak memiliki cukup waktu untuk menyiapkan makanan yang bergizi dan beraneka ragam setiap hari, sehingga para ibu cenderung menyajikan makanan yang cepat saji. ${ }^{17,18}$ Makanan cepat saji dengan proses memasak yang cenderung cepat memang sangat membantu saat ibu tidak memiliki cukup banyak waktu. Menurut dr. Fiastuti Wicaksono, Sp.GK dari Departemen Ilmu Gizi, Fakultas Kedokteran Universitas Indonesia, makanan jenis ini sudah mengalami proses pemasakan terlebih dahulu sehingga banyak kehilangan zat gizi penting. Zat-zat gizi yang seharusnya diproses dalam saluran cerna tidak lagi dilakukan. Akibatnya zat gizi lebih cepat dicerna dan diserap, metabolisme di dalam tubuh pun menjadi kurang baik. Lama kelamaan asupan gizi anak menjadi tidak seimbang. Fast food cenderung mengandung lemak tinggi dan gula tinggi, protein dan minim serat. Anak yang sering mengonsumsi fast food cenderung mengalami obesitas bila tidak diawasi. ${ }^{20}$ Pengetahuan gizi sangat dibutuhkan dalam pemilihan bahan makanan sehingga pemenuhan gizi seimbang pada anak dapat tercapai. $^{22}$

\section{Gambaran erupsi gigi permanen siswa SD Negeri 70 Manado}

Erupsi ialah pergerakan gigi ke arah rongga mulut yang dimulai pada saat gigi masih berada dalam rahang dan merupakan proses yang bervariasi pada setiap anak. 6,14 Masing - masing gigi pada tiap individu memiliki waktu erupsi yang berbeda-beda. Gigi dikatakan sudah erupsi apabila gigi sudah mulai terlihat muncul pada permukaan rongga mulut sebaliknya gigi dikatakan belum erupsi apabila belum nampak pada permukaan rongga mulut.

Berdasarkan data hasil pemeriksaan secara visual mengenai erupsi gigi permanen siswa yang dilakukan di SD Negeri 70 Manado didapati 44,58\% belum erupsi dan 55,42\% sudah erupsi. Hal ini menunjukkan bahwa secara umum keadaan erupsi gigi permanen siswa SD Negeri 70 Manado berjalan normal sesuai usia kronologis pertumbuhan gigi.

\section{Hubungan status gizi dengan erupsi gigi permanen siswa SD Negeri 70 Manado}

Terdapat banyak teori yang dikemukakan berdasarkan proses awal munculnya gigi atau erupsi gigi. Brauer menjelaskan bahwa prinsip biologi digunakan untuk mengontrol pertumbuhan gigi. Oleh karena itu, variasi akan terjadi pada proses erupsi gigi. ${ }^{6}$ Steggerda menambahkan bahwa tidak hanya faktor biologi yang dapat memengaruhi proses pertumbuhan gigi namun terdapat faktor lokal, gizi dan lingkungan yang juga berperan penting pada proses erupsi gigi. ${ }^{16}$

Status gizi merupakan salah satu hal 
yang harus diperhatikan dan tidak bisa disepelekan oleh orang tua terlebih pada saat anak berada dalam periode emas pertumbuhannya, dalam hal ini periode pertumbuhan dan perkembangan gigi anak. Berdasarkan hasil penelitian Almonaitiene di Lithuania, dikemukakan bahwa kekurangan gizi merupakan salah satu faktor yang memengaruhi keterlambatan erupsi gigi permanen anak. ${ }^{7}$

Status gizi yang baik sangat dibutuhkan untuk menunjang pertumbuhan dan perkembangan gigi serta dalam menjaga keseimbangan lingkungan mulut yang dihubungkan dengan kesehatan gigi. Keadaan status gizi yang tidak baik pada anak-anak dapat menimbulkan akibat yang berkepanjangan pada fungsi biologis, jaringan keras dan lunak serta kelenjar saliva, sehingga nantinya dapat berdampak pada erupsi gigi. ${ }^{19}$

Hasil penelitian menunjukkan bahwa responden dengan kategori status gizi baik, status gizi gemuk dan sangat gemuk lebih banyak memiliki gigi permanen yang sudah erupsi sesuai usia erupsinya daripada yang berstatus gizi kurus. Responden dengan status gizi kurus lebih banyak memiliki gigi permanen yang belum erupsi sesuai usia erupsinya.

Kategori status gizi kurus dengan jumlah total 15 responden, 11 di antaranya dengan keadaan erupsi gigi belum erupsi dan 4 responden dengan keadaan erupsi gigi sudah erupsi. Hal ini sejalan dengan penelitian yang dikemukakan oleh Windratih yang menyatakan bahwa pada anak-anak dengan status gizi kurus pertumbuhan gigi permanennya lebih lambat dibandingkan dengan anak-anak yang mempunyai status gizi baik. ${ }^{12}$ Penelitian lain juga mengemukakan hal yang sama yaitu penelitian dari Schuurs yang mengemukakan bahwa kekurangan gizi yang berat dapat memengaruhi pertumbuhan badan yang ditentukan oleh panjang dan berat badan sehingga terdapat korelasi dengan tertundanya kemunculan gigi. $^{23}$

Responden dengan kategori status gizi baik berjumlah 49 siswa, 26 di antaranya memiliki gigi permanen yang sudah erupsi sesuai dengan usia erupsi giginya dan sisanya sejumlah 23 siswa memiliki gigi permanen yang belum erupsi (terlambat erupsi). Hal ini berbeda dengan yang dikemukakan pada beberapa penelitian sebelumnya yaitu penelitian dari Syahfriza dan Indriyanti bahwa anak dengan status gizi baik ialah anak yang memiliki berat badan dan tinggi badan ideal sesuai usianya dan cenderung memiliki pertumbuhan dan perkembangan gigi yang sesuai dengan usia erupsinya. ${ }^{9,12,14}$ Kenyataannya dari total jumlah 49 siswa dengan kategori status gizi baik, 23 di antaranya mengalami keterlambatan erupsi gigi. Hal ini mungkin disebabkan oleh faktor lain seperti faktor lingkungan, sosial ekonomi dan faktor lokal. ${ }^{7}$ Penelitian lain yang mendukung hasil penelitian ini yakni hasil penelitian dari Oktavianus yang menyatakan bahwa tidak terdapat hubungan yang berarti antara status gizi baik dengan erupsi gigi permanen anak yang mungkin disebabkan oleh faktor genetik, ras, hormonal dan jaringan di sekitar gigi misalnya ligamen periodontal yang mendorong gigi ke permukaan gigi. Hal-hal tersebut jauh lebih berpengaruh pada erupsi gigi permanen anak dibandingkan dengan status gizi beserta alasan lainnya, yaitu berupa penggunaan timbangan berat badan yang tidak terkalibrasi sehingga memungkinkan kesalahan pada pengukuran berat badan. ${ }^{24}$

Responden dengan kategori status gizi gemuk berjumlah 8 siswa, 7 siswa di antaranya memiliki gigi permanen yang sudah erupsi sesuai waktunya dan 1 lainnya memiliki gigi permanen yang belum erupsi atau terlambat erupsi. Hal ini sejalan dengan penelitian dari Surya Irayadi yang menyatakan bahwa pada anak dengan status gizi gemuk biasanya gigi permanen sudah erupsi atau bahkan erupsi dini atau erupsi lebih cepat dari waktu erupsinya. Namun pada kasus tertentu anak dengan status gizi gemuk mengalami keterlambatan erupsi gigi akibat konsumsi jajanan secara berlebihan yang mengkibatkan kerusakan gigi yang dapat menghambat pertumbuhan gigi. ${ }^{25}$ 
Jumlah responden dengan kategori status gizi sangat gemuk atau obesitas yaitu 11 siswa. Sebanyak 9 siswa di antaranya memiliki gigi permanen yang sudah erupsi sesuai waktunya dan 2 siswa lainnya mengalami keterlambatan erupsi atau belum erupsi. Hal ini tidak jauh berbeda dengan hasil penelitian untuk kategori status gizi sangat gemuk, yaitu bahwa pada anak dengan status gizi sangat gemuk biasanya gigi permanennya sudah erupsi atau bahkan erupsi dini sebelum waktunya. ${ }^{24}$ Pada kategori status gizi sangat gemuk dengan keterlambatan erupsi gigi, biasanya berkaitan dengan konsumsi jajanan secara berlebihan sehingga berakibat terjadinya karies gigi yang menghambat proses erupsi gigi permanen. ${ }^{25}$

\section{SIMPULAN}

1. Status gizi siswa SD Negeri 70 Manado sebagian besar memberikan gambaran status gizi baik kemudian diikuti oleh status gizi kurus, obesitas dan gemuk.

2. Erupsi gigi permanen siswa SD Negeri 70 Manado memberikan gambaran gigi permanen yang sudah erupsi sesuai usia erupsinya lebih besar jumlahnya dan gigi permanen yang belum erupsi atau terlambat erupsi lebih sedikit jumahnya.

3. Hasil uji statistik menunjukkan bahwa terdapat hubungan yang signifikan antara status gizi dan erupsi gigi permanen siswa SD Negeri 70 Manado.

\section{SARAN}

1. Disarankan kepada Dinas kesehatan dalam hal ini pihak Puskesmas Bahu, agar dapat memanfaatkan hasil penelitian sebagai bahan kajian untuk penyusunan program preventif dan promotif guna meningkatkan derajat kesehatan masyarakat termasuk derajat kesehatan gigi dan mulut masyarakat yang berada di wilayah kerjanya.

2. Disarankan kepada masyarakat untuk dapat mengaplikasikan segala informasi yang diperoleh melalui puskesmas untuk peningkatan status gizi dan status kesehatan secara umum termasuk kesehatan gigi dan mulut.

\section{DAFTAR PUSTAKA}

1. Depkes RI. Gizi seimbang atasi masalah gizi ganda. Jakarta: Komukasi Publik Sekretariat Jenderal Kementrian Kesehatan RI; 2012. p. 2-3.

2. Almatsier S. Prinsip dasar ilmu gizi. Jakarta: Gramedia Pustaka Utama; 2000. p. 4-9.

3. Almatsier S. Gizi seimbang dalam daur kehidupan. Jakarta: Gramedia Pustaka Utama; 2011. p. 213-77.

4. Smolin LA, Grosvenor MB. Basic nutrition. New York: Infobase Publishing; 2005. p. 6-12.

5. Chaterjee M, Bandyophadyay AR. A study on nutritional status and dental caries in permanent teeth among school. Scientific Research; 2012. Vol. 2, No. 3. p. 112-16.

6. Brauer JC. Dentistry for children. New York: Mcgraw Hill Book Company inc; 1959. p. 263-77.

7. Almonaitiene R, Balciuniene I, Tutkuviene J. Factor influencing permanen teeth eruption. Stimatologija, Baltic Dental and Maxillofacial Journal Vol. 12 No.3. p. 67-70.

8. Makalew YM, Kawengian SES, Malonda NHS. Hubungan antara asupan energi dan zat gizi dengan status anak sekolah dasar. Manado: Program Studi Gizi Masyarakat. Universitas Sam Ratulangi; 2013. p. 2-4.

9. Fidiantoro N, Setiadi T. Model penentuan status gizi balita di puskesmas. Jurnal Sarjana Teknik Informatika. Yogyakarta: 2013 Vol. 1 No. 1. p. 367-9.

10.Kemenkes RI. Riset kesehatan dasar. Jakarta: Badan penelitian dan pengembangan kesehatan Kemenkes; 2010. p. 52-54.

11.Supariasa. Penilaian status gizi. Jakarta: Buku Kedokteran EGC Gramedia Pustaka Utama; 2001. p. 22-58.

12.Windratih RD. Hubungan status gizi dengan erupsi gigi permanen anak. Universitas Hasanudin [internet]. 2010 [diakses pada 2013 Agu 15]. Tersedia dari: http://repository.unhas.ac.id./handle/1 23456789/2756.

13.Indriyanti R, Pertiwi ASP, Sasmita IS. Laporan penelitian pola erupsi gigi 
permanen ditinjau dari usia kronologis pada anak usia 6-12 tahun. Sumedang: Universitas Padjajaran; 2006. p. 5-6.

14.Itjiningsih WH. Anatomi gigi. Jakarta: EGC; 1991. p. 211-48.

15.Bertech R. Vitamin and mineral keep teeth healthy. [internet] 2012. [cited 2013 Jul 22]. Available from: http:// dentistryloveland.com/dentist/

16.Steggerda M, Hill T.J. Eruption time of teeth among Whites Nogroes and Indians. Department of Genetics, Carnegie Institution of Washington, Cold Spring Harbor, Long island, New York, USA.

17.American Journal of Orthodontics and Oral Surgery; June 1942, Vol 28(6). p. 361-70.

18.Suhardjo. Pangan, gizi dan pertanian. Jakarta: UI Press. 2000. p. 8-9.

19.Naidoo S. Oral health and nutrition. Cape Town: Department of community oral health; 2000. p. 131-2.

20.Kusumawati R. Hubungan tingkat keparahan karies dengan status gizi siswa SDN 01 Ciangsana kabupaten
Bogor. Jakarta: Universitas Islam Syarif Hidayatullah, 2010; p. 82.

21. Wicaksono F. Mengupas kandungan gizi fast food - parenting mobile Indonesias [internet] 2015 [diakses 9 Feb 2015]. Tersedia di: http:// www.parenting.co.id/article/... gizi...656

22.Misnadiarly. Obesitas sebagai faktor resiko beberapa penyakit. Jakarta: Pustaka Obor, 2007; p. 3-5.

23.Moehji, Syahmien. Ilmu gizi. Jakarta: PT Bhatara Karya Aksara; 2013

24.Schuurs. Patologi gigi geligi, kelainankelainan jaringan keras gigi. Yogyakarta: Gadjah Mada University Press, 1992; p.121.

25. Oktavianus $\mathbf{P}$. Hubungan antara status gizi dengan erupsi gigi molar 1 permanen. Makassar: Fakultas Kedoteran Gigi niverss Hasanudin, 2008;. p. 4-7.

26.Irayani S. Hubungan antara indeks massa tubuh dengan erupsi gigi molar pertama permanen rahang atas dan rahang bawah anak umur 6 dan 7 tahun SD Inpres Perumnas. Makasar: Politeknik Kesehatan, 2013; p. 49. 